Utah State University

DigitalCommons@USU

\title{
Estimating plant biomass for undergrowth species of northeastern Minnesota forest communities
}

\author{
L.F. Ohmann \\ D.F. Grigal \\ L.L. Rogers
}

Follow this and additional works at: https://digitalcommons.usu.edu/aspen_bib

Part of the Forest Sciences Commons

\section{Recommended Citation}

Ohmann, Lewis F.; Grigal, David F.; Rogers, Lynn L. 1981. Estimating plant biomass for undergrowth species of northeastern Minnesota forest communities. General Technical Report NC-61. St. Paul, MN: U.S. Dept. of Agriculture, Forest Service, North Central Forest Experiment Station

This Report is brought to you for free and open access by the Aspen Research at DigitalCommons@USU. It has been accepted for inclusion in Aspen Bibliography by an authorized administrator of DigitalCommons@USU. For more information, please contact

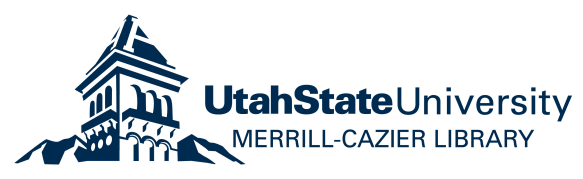




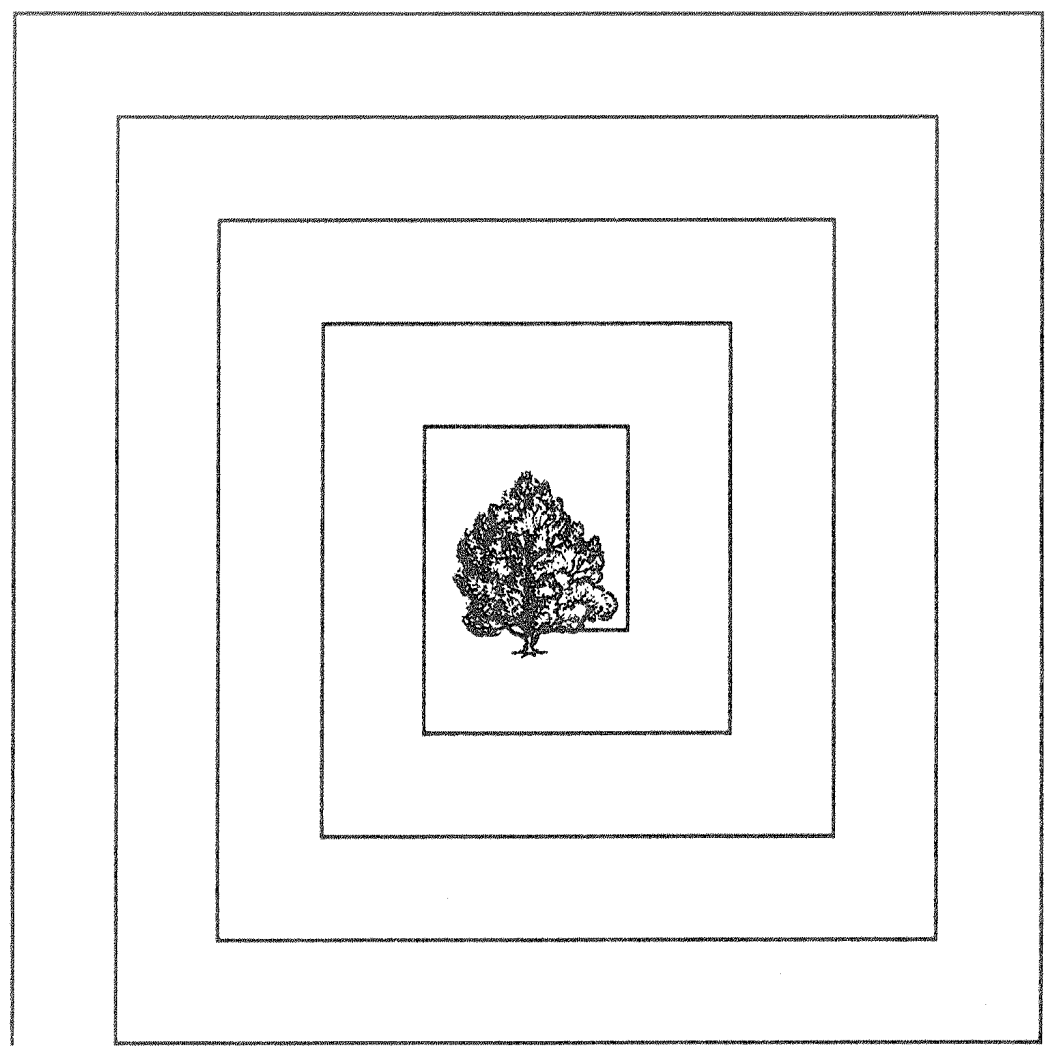

Estimating plant biomass for undergrowth species of northeastern Minnesota

Lewis F. Ohmann, David F. Grigal, and Lynn L. Rogers 
North Central Forest Experiment Station Forest Service-U.S. Department of Agriculture 1992 Folwell Avenue

St. Paul, Minnesota 55108

Manuscript approved for publication January 16,1980 


\section{ACKNOWLEDGMENT}

We gratefully acknowledge the help of field assistants Sheila Arimond, Nancy Berlin, Kathy Brosdahl, Stephen Burch, Paul Conklin, Grant Cornwell, Rick Field, David Guertin, Kathleen Hunt, Mark Korb, Laura Mason, Gerald McCarthy, Sue McDonald, Laura Medved, Carol Schmidt, Mary Shedd, Adele Schultz, and Steven Wilson. 


\title{
ESTIMATING PLANT BIOMASS FOR UNDERGROWTH SPECIES OF NORTHEASTERN MINNESOTA FOREST COMMUNITIES
}

\author{
Lewis . Ohmann, Principal Plant Ecologist, \\ North Central Forest Experiment Station, \\ David F. Grigal, Professor, \\ Department of Soil Science and Forest Resources, \\ University of Minnesota, \\ and Lynn L. Rogers, Wildlife Biologist, \\ North Central Forest Experiment Station, St. Paul, Minnesota
}

Knowledge of the plant biomass comprising a forest community is important to many aspects of multipleuse management. Direct measurement of biomass, however, is expensive and time-consuming to undertake each time biomass information would be useful. Fortunately, other measurements that can be made in the field less expensively or more easily can be used for estimating biomass.

Biomass prediction equations based on stem diameters have been available for several decades for the more important tree species. Similar equations for biomass of shrubs and their components have been developed more recently (Ohmann et al. 1976, Brown 1976, and others). With increased application (for example, estimating browse availability for hares (Grigal and Moody 1980)), these equations are being refined and extended and will become more useful for multiple-use management decisions, such as determining the carrying capacity for wildlife of a habitat in terms of woody browse. Determination of wildlife carrying capacity could be more meaningful if, along with better knowledge of food preferences, equations to predict biomass of ground cover plants could be developed.

Presented here are biomass prediction curves and equations, based on percent ground cover for 31 undergrowth plants typical of upland forest communities of northeastern Minnesota. Perhaps their publication will stimulate further development and/or refinement to improve their performance and to extend their application to a broader area and a greater variety of vegetative types (Payne 1974).

\section{METHODS}

Percent cover was estimated visually for each undergrowth species present in 1,0601 - by 2 -ft $\left(1,800 \mathrm{~cm} /{ }^{2}\right)$ plots, 660 located in aspen (Populus tremuloides Michx.) and 400 in red pine (Pinus resinosa Ait.) stands. The stands ranged from recently clearcut to more than 80 years old. Stands were 20 acres ( 8 ha) or larger with plots distributed systematically at $60-\mathrm{ft}(20-\mathrm{m})$ intervals along transects that crossed topographic contours or recognizable banding in soils or vegetation. All plots were at least 20 paces $(20 \mathrm{~m})$ from stand edges, and no more than 20 plots were sampled in each stand.

At each plot, we estimated percent cover and clipped and separately bagged all plants of each undergrowth species present. Portions of plants that extended outside plots were discarded. The bagged plants were oven-dried at $68 \mathrm{C}$ for 48 hours and weighed.

The relation between percent cover and biomass was first explored with scatter diagrams. Results for a large number of species showed that a log-log plot of cover and biomass data was linear. This linearity can be expressed by the allometric relation

$$
\mathrm{Y}=\mathrm{a} \mathrm{X}^{\mathrm{b}}
$$

where $\mathrm{Y}$ is plant biomass in grams dry weight and $\mathrm{X}$ is ground cover in percent. We used an iterative nonlinear approach to determine the appropriate parameters for each species. Where sufficient observations were available (arbitrarily set at 15 plots) the data were treated by species. Where fewer plots were available for a single species, species were grouped by genus or treated as miscellaneous fern, herb, and shrub groups.

The solutions for each species (or group) are the a and $b$ parameters and their approximate 95 percent confidence intervals. The program also calculates a joint confidence interval for the function (in the sense that the confidence regions for $a$ and $b$ vary jointly.) 
These confidence intervals are not uniform in the nonlinear case and cannot be easily described by a single algorithm. Thus, we present the results graphically to allow users to more easily approximate the confidence interval along various parts of the regression line.

Equations were developed separately for data collected in the aspen and red pine stands, but because confidence intervals overlapped, the data were combined and the parameters redetermined using the entire data set. Biomass values resulting from use of the prediction equations are for a $2-\mathrm{ft}^{2}\left(1,800-\mathrm{cm}^{2}\right)$ area. These area values can be expanded to provide estimates on a per-acre (ha) basis.

\section{LITERATURE CITED}

Brown, James K. 1976. Estimating shrub biomass from basal stem diameters. Canadian Journal of Forest Research 6(2):153-158.

Grigal, D. F., and N. R. Moody. 1980. Estimation of browse by size classes for snowshoe hare. Journal of Wildlife Management 44(1):34-40.

Ohmann, Lewis F., David F. Grigal, and Robert B. Brander. 1976. Biomass estimation for five shrubs from northeastern Minnesota. U.S. Department of Agriculture Forest Service, Research Paper NC. 133, 11 p. U.S. Department of Agriculture Forest Service, North Central Forest Experiment Station, St. Paul, Minnesota.

Payne, Gene F. 1974. Cover-weight relationships. Journal of Range Management 27(5):403-404. 
Nonlinear regressions (allometric relation $\mathrm{Y}=\mathrm{aX}^{\mathrm{b}}$ ) of biomass (in grams) on cover (in percent), the 95 percent confidence interval about the regressions, the equation parameters, standard errors of the estimates, and $R^{2}$ values for a number of species or species groups from forest communities in northeastern Minnesota. Equation prediction values are for a 1 - by 2 -ft $(1,800$ $\mathrm{cm}^{2}$ ) area.
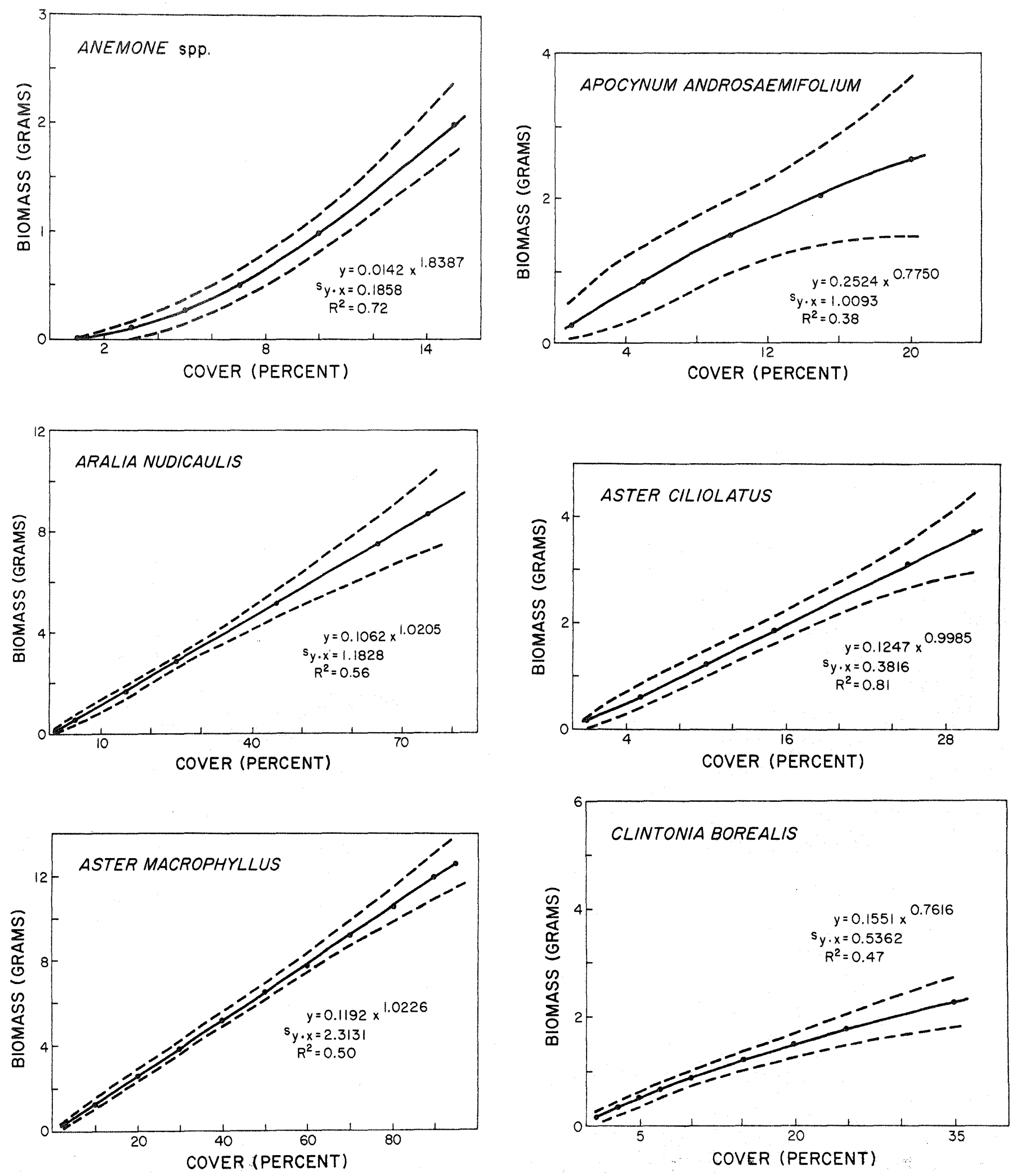

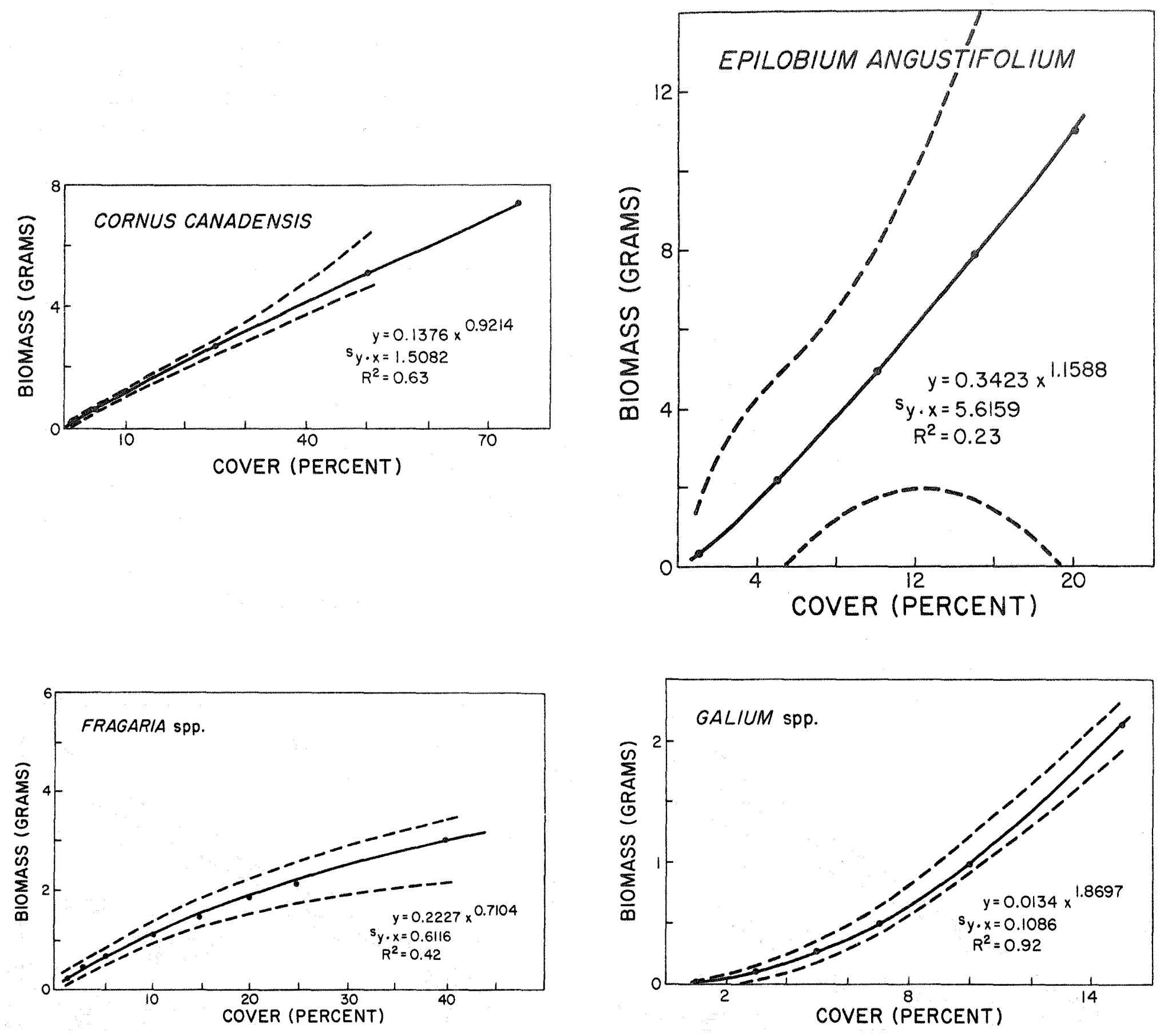

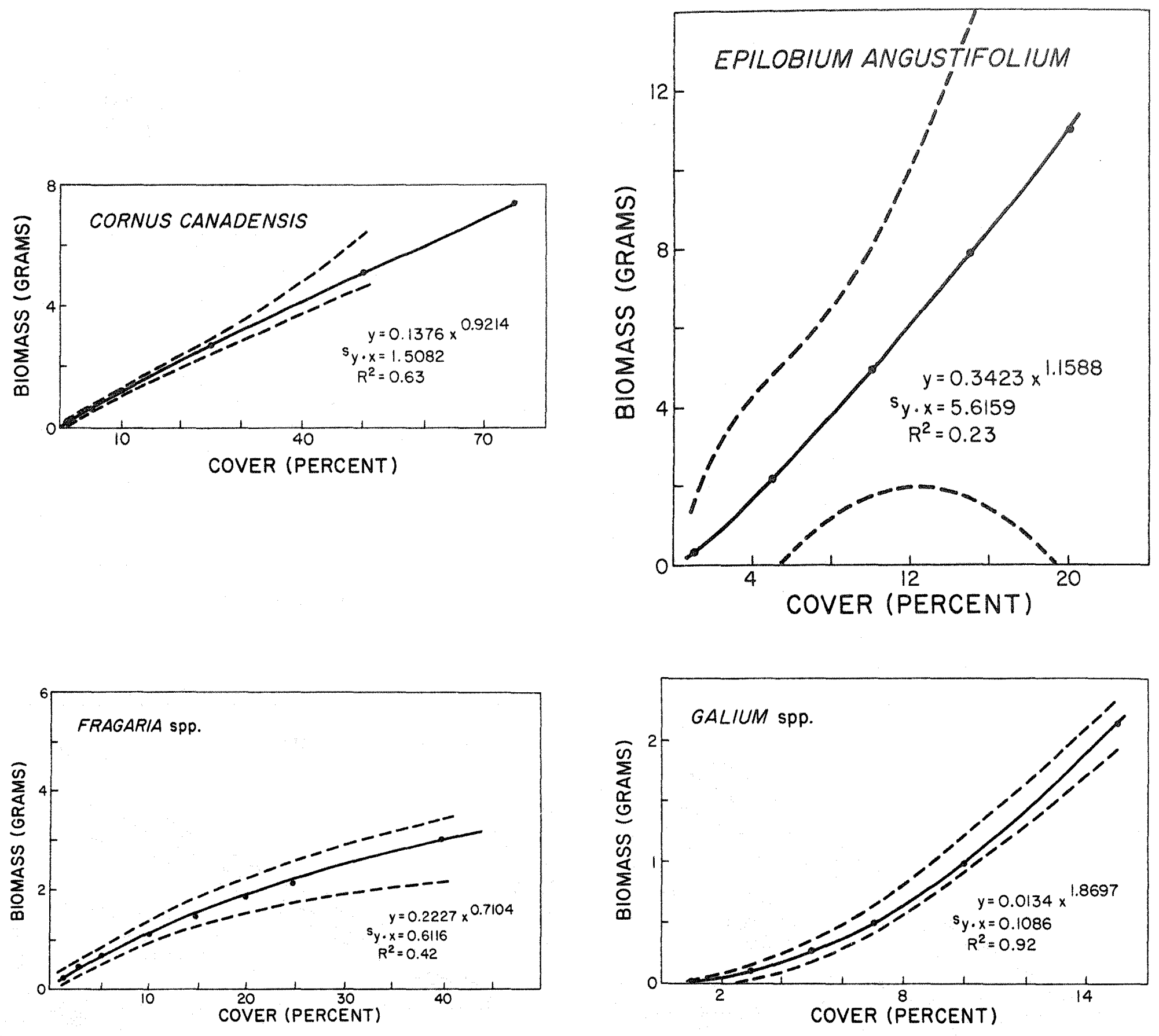

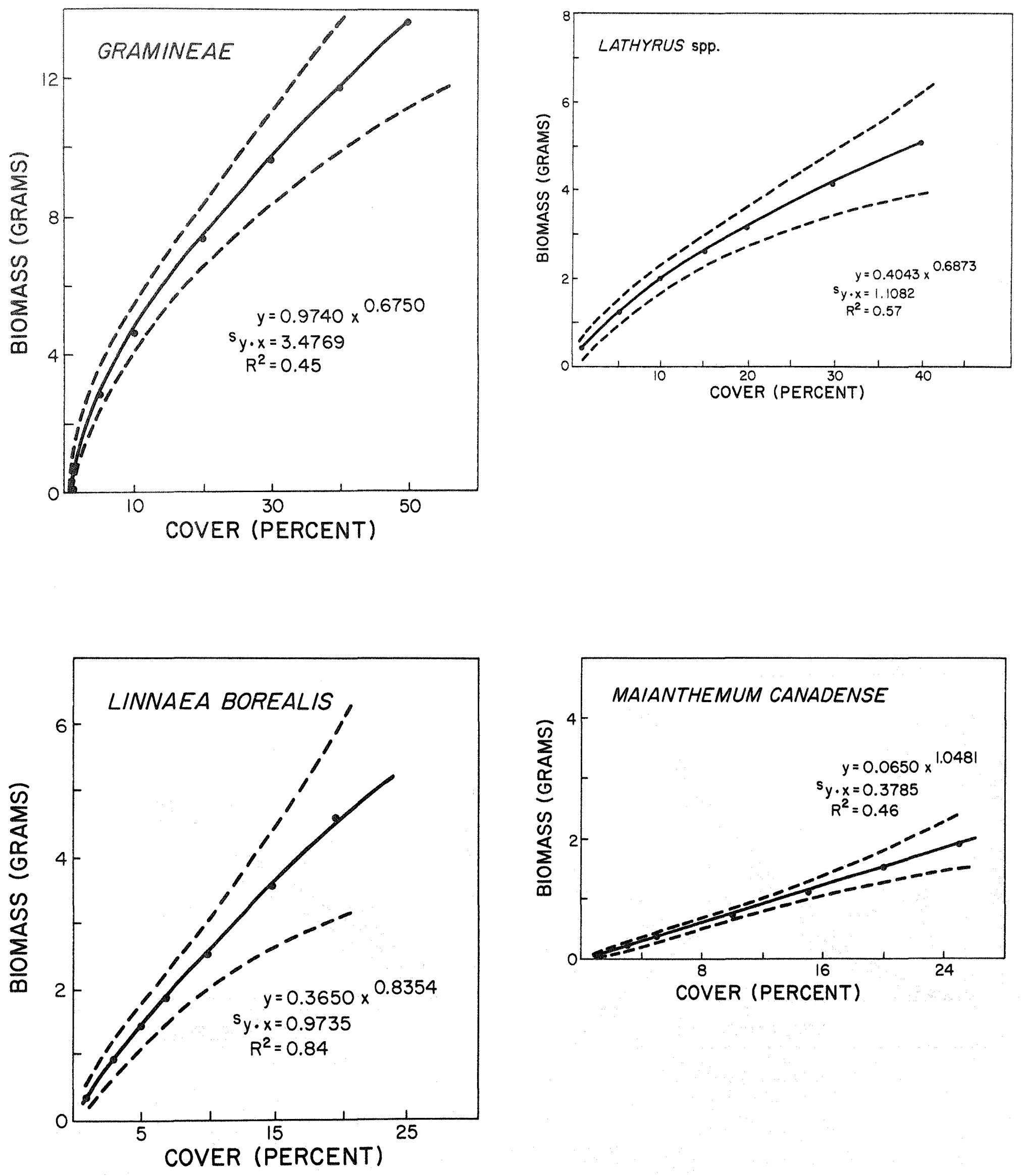

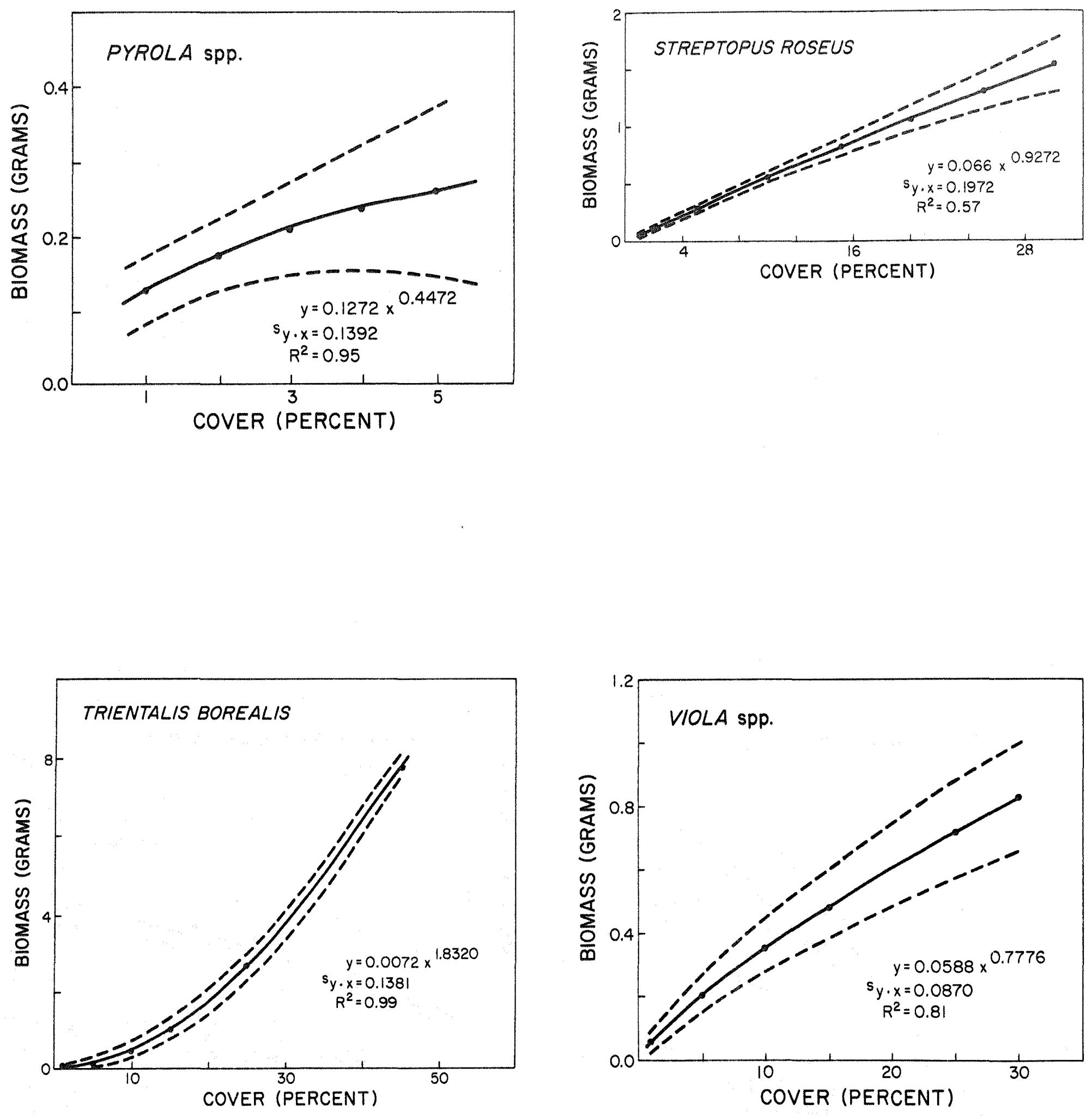

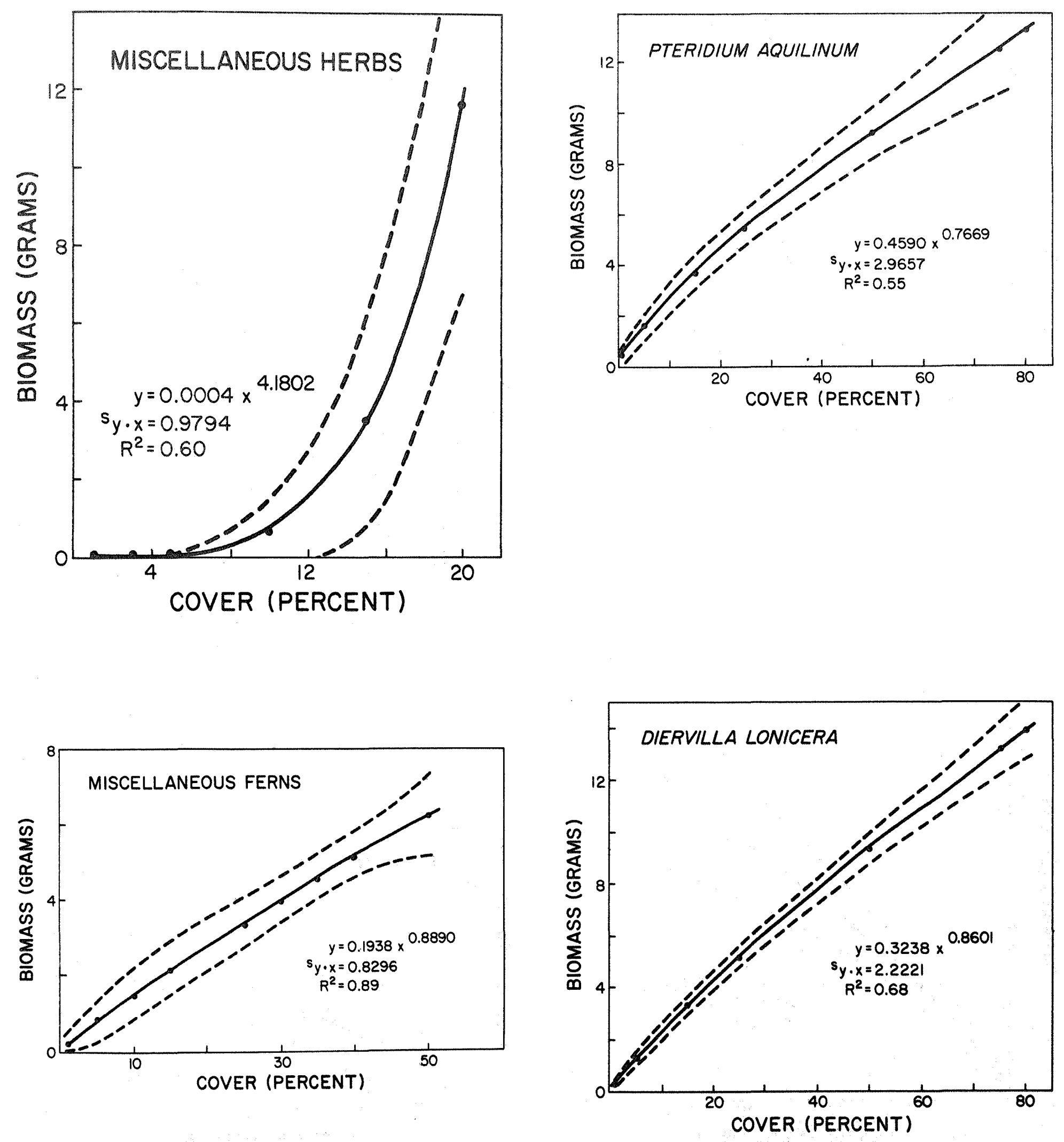

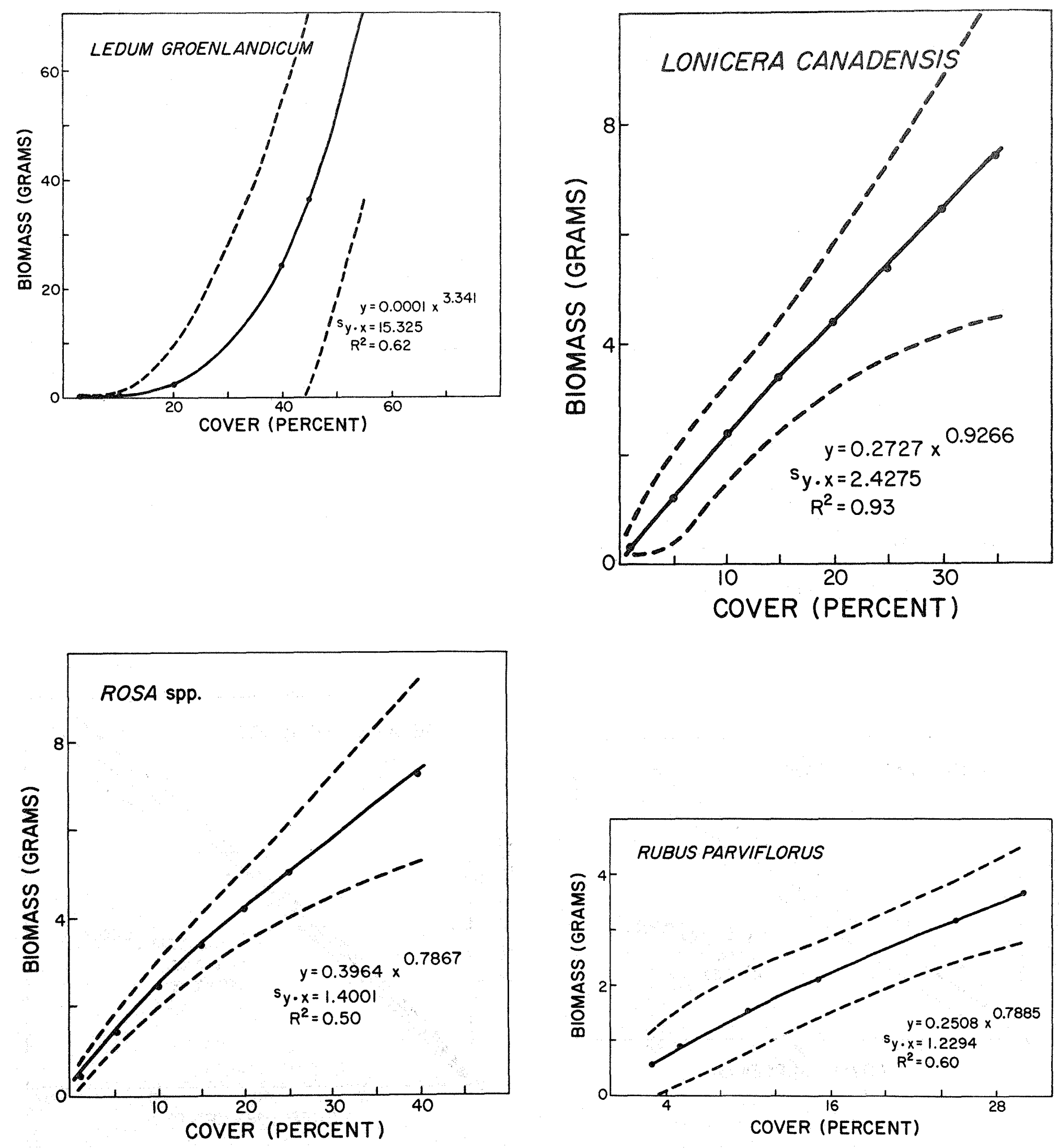

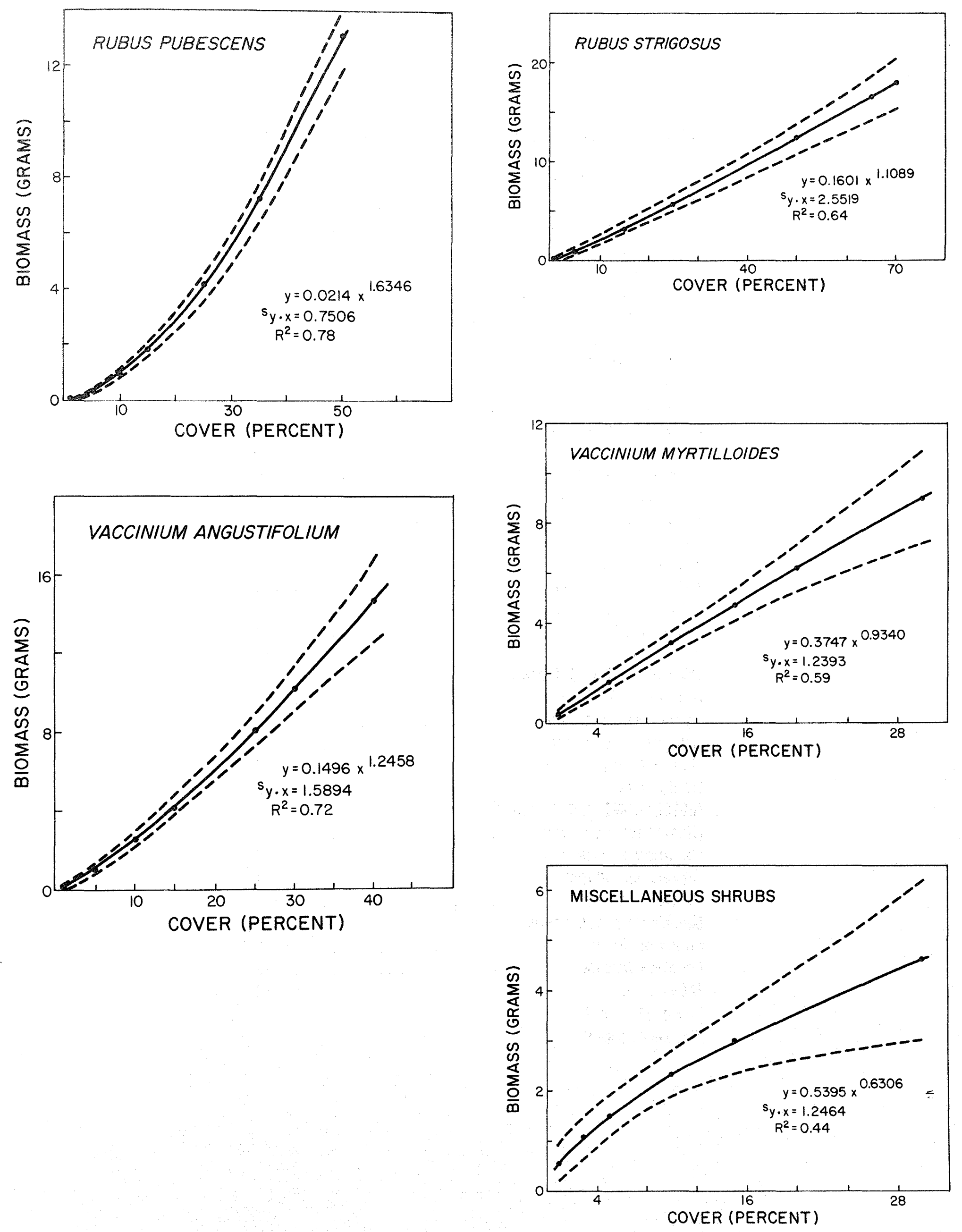


\section{MISCELLANEOUS HERBS ${ }^{1}$}

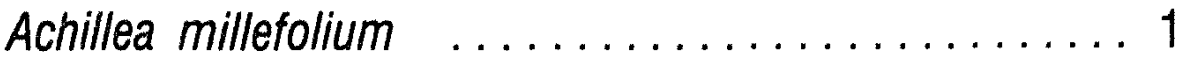

Actaea rubra $\ldots \ldots \ldots \ldots \ldots \ldots \ldots \ldots \ldots, 2$

Anaphalis margaritacea .................... 1

Bidens connata ........................ 1

Carex spp. .......................... 4

Coptis groenlandica $\ldots \ldots \ldots \ldots \ldots \ldots \ldots \ldots 13$

Equisetum spp. ......................... 2

Goodyera repens $\ldots \ldots \ldots \ldots \ldots \ldots \ldots \ldots \ldots, 4$

Halenia deflexa $\ldots \ldots \ldots \ldots \ldots \ldots \ldots \ldots \ldots . . \ldots 1$

Hapatica americana ........................ 2

Lactuca spp. ........................ 1

Melampyrum lineare $\ldots \ldots \ldots \ldots \ldots \ldots \ldots \ldots 1$

Mitella nuda ........................ 8

Petasites palmatus ......................10

Polygala paucifolia $\ldots \ldots \ldots \ldots \ldots \ldots \ldots \ldots . \ldots 2$

Potentilla norvegica $\ldots \ldots \ldots \ldots \ldots \ldots \ldots \ldots 1$

Rumex spp. ........................ 2

Solidago spp. $\ldots \ldots \ldots \ldots \ldots \ldots \ldots \ldots \ldots, 6$

Taraxacum officinale $\ldots \ldots \ldots \ldots \ldots \ldots \ldots \ldots \ldots 1$

Trillium spp. $\ldots \ldots \ldots \ldots \ldots \ldots \ldots \ldots \ldots \ldots, \ldots \ldots$

Unidentified $\ldots \ldots \ldots \ldots \ldots \ldots \ldots \ldots \ldots, \ldots$

Vicia americana ........................13

MISCELLANEOUS FERNS ${ }^{1}$

Athyrium filix-femina ...................... 8

Cynoglossum boreale $\ldots \ldots \ldots \ldots \ldots \ldots \ldots \ldots 1$

Dryopteris phegopteris $\ldots \ldots \ldots \ldots \ldots \ldots \ldots \ldots \ldots 1$

Osmunda claytoniana $\ldots \ldots \ldots \ldots \ldots \ldots \ldots \ldots 2$

Unidentified $\ldots \ldots \ldots \ldots \ldots \ldots \ldots \ldots, \ldots, \ldots$

\section{MISCELLANEOUS SHRUBS ${ }^{2}$}

Chimaphila umbellata ..................... 3

Comptonia peregrina $\ldots \ldots \ldots \ldots \ldots \ldots \ldots \ldots 1$

Cornus stolonifera ....................... 1

Corylus cornuta ......................... 1

Gaultheria procumbens ................... 7

Lonicera dioica ......................... 5

Lonicera hirsuta $\ldots \ldots \ldots \ldots \ldots \ldots \ldots \ldots \ldots 12$

Ribes spp. ........................

'See graph, page 7.

${ }^{2}$ See graph, page 9 . 
Ohmann, Lewis F., David F. Grigal, and Lynn L. Rogers,

1981. Estimating plant biomass for undergrowth species of northeastern Minnesota forest communities. U.S. Department of Agriculture Forest Service, General Technical Report NC-61, 10 p. U.S. Department of Agriculture Forest Service, North Central Forest Experiment Station, St. Paul, Minnesota.

Biomass prediction equations were developed for some common ground cover plants from forest communities of northeastern Minnesota. The allometric function was used to predict biomass (dry weight) with ocular estimates of percent ground cover of the plant as the independent variable.

KEY WORDS: Wildlife habitat, nonlinear regression analysis, allometric relations, dry weight, plant ecology. 